\title{
Insight
}

\section{Naturalness and Place in River Rehabilitation}

\author{
Kirstie Fryirs $^{1}$ and Gary J. Brierley $^{2}$
}

\begin{abstract}
An authentic approach to river rehabilitation emphasizes concerns for the natural values of a given place. As landscape considerations fashion the physical template upon which biotic associations take place, various geomorphic issues must be addressed in framing rehabilitation activities that strive to improve river health. An open-ended approach to river classification promotes applications that appreciate the values of a given river, rather than pigeonholing reality. As the geomorphic structure of some rivers is naturally simple, promoting heterogeneity as a basis for management may not always be appropriate. Efforts to protect unique attributes of river systems must be balanced with procedures that look after common features. Concerns for ecosystem functionality must relate to the behavioral regime of a given river, remembering that some rivers are inherently sensitive to disturbance. Responses to human disturbance must be viewed in relation to natural variability, recognizing how spatial relationships in a catchment, and responses to past disturbances, fashion the operation of contemporary fluxes. These fluxes, in turn, influence what is achievable in the rehabilitation of a given reach. Given the inherently adjusting and evolutionary nature of river systems, notional endpoints do not provide an appropriate basis upon which to promote concepts of naturalness and place in the rehabilitation process. These themes are drawn together to promote rehabilitation practices that relate to the natural values of each river system, in preference to applications of "cookbook" measures that build upon textbook geomorphology.
\end{abstract}

Key Words: connectivity; heterogeneity; physical integrity; river evolution; river health; river process

\section{INTRODUCTION: NATURALNESS AND PLACE IN RIVER REHABILITATION}

Goals of river rehabilitation programs vary from system to system, reflecting combinations of socioeconomic, cultural, and biophysical values of a given place. These factors determine what is realistically achievable and what is desired in any given catchment. Societal perceptions are shaped largely by cultural and esthetic values (e.g., Junker and Buchecker 2008). These perspectives are partly experiential (based on familiarity and worldviews) and partly aspirational (the kind of society and environment we would like to live within). A mechanistic worldview may savor the elegant simplicity and hydraulic efficiency of a fully regulated, smooth, well-behaved canal that supports a limited range of aquatic flora and fauna. To others, a more natural, self-adjusting, dynamic, "messy" river that supports a range of native flora and fauna is desired (e.g., Kondolf 2006).
In this paper, various geomorphic themes related to naturalness are outlined that the authors feel are integral issues in the quest to improve river condition at any given place. The intent is to challenge prevailing mindsets of many river restorationists to provide guidance on measures that work with nature rather than re-engineer nature, encouraging practitioners to move beyond "cookbook" approaches to river rehabilitation that unintentionally promote a placeless universalism (see Simon et al. 2007). Geomorphic principles of naturalness and place are considered to underpin ecosystem integrity as a basis for effective river rehabilitation, as landscape considerations fashion the physical template upon which biotic associations take place (Brierley and Fryirs 2008). This geomorphic perspective, in turn, determines the physical integrity of a river, providing a basis to promote resilient and self-sustaining systems. Such thinking is considered to be an integral underpinning of authentic, grounded approaches to river rehabilitation (Hillman and Brierley 2005). 
Notions of naturalness continue to provoke passionate arguments and perspectives among researchers (e.g., Montgomery 2008, Wohl and Merritts 2007). However, it is the attitude of managers, stakeholders, and the community to such matters that forms the backbone of rehabilitation practice. Is naturalness some form of historical state, a good condition reference reach, or an artificial preconception of what the river should be like (e.g., Kondolf 2006)? A geomorphic perspective views a natural river as one that is appropriate for the given landscape or environmental setting, with a character and behavior that is expected given the boundary conditions under which the river operates (Brierley and Fryirs 2005). In this way, naturalness is not embedded in the past. Rather, it is a functional state that adjusts its character and behavior in response to flow, sediment, and vegetation fluxes (Brierley and Fryirs 2005, Hughes et al. 2005). Unless perceptions of naturalness allow for evolution and change (in its broadest sense), it could be argued that rehabilitation activities are managing for historical relicts rather than river futures (cf. Brierley and Fryirs 2008).

The approach adopted here targets naturalness as the key underlying goal for rehabilitation activities, promoting benefits in both ecological and economic terms. A "place-based guiding image" is considered to provide the best way to undertake rehabilitation practice, focusing attention upon field-based insights into naturalness. This entails critical thinking in the application of management techniques, using them as learning tools rather than prescriptive mechanisms with which to impose a fixed template upon any given reach. Inherent dangers in using reference conditions to derive notional endpoints are highlighted, reframing perspectives to emphasize concerns for living, evolving rivers (Everard and Powell 2002). Use of guiding images framed in relation to naturalness involves consideration of representativeness (diversity), the range of behavior (dynamic), and evolutionary trajectory and prevailing fluxes. In this way, reference conditions provide a guide, not a template, with which to apply rehabilitation practices (Hilderbrand et al. 2005, Hughes et al. 2005). The key question to ask in determination of reference reaches is: representative of what?

In answering this question, authentic approaches to river rehabilitation must challenge dominant mindsets that pervade contemporary management approaches in many parts of the world. Firstly, field evidence should be used to inform and guide rehabilitation practice, rather than relying on cookbook applications of textbook knowledge. Respecting the diversity of river forms in any given catchment provides the baseline upon which to work. Secondly, rehabilitation practice should be framed around how a river works and adjusts (its range of behavior), rather than what it looks like, ensuring that practice moves beyond perspectives that attempt to "fix" a river in place. Thirdly, rehabilitation programs should be appropriately framed in relation to the spatial and temporal context of any given activity. Due regard should be given to treatment responses, highlighting how adjustments in any given reach will have off-site consequences. Catchment-scale considerations are required to identify threatening processes and limiting factors that may compromise the effectiveness of rehabilitation practices. Activities should also be framed in relation to evolutionary trajectory, striving to ensure that short-term benefits are not achieved at the cost of longer-term losses, hindering the capacity of future generations to address these concerns. This opinion piece considers each of these issues by posing a series of questions that practitioners should address in efforts to rehabilitate river systems.

\section{RIVER DIVERSITY, RIVER BEHAVIOR, AND SPATIAL AND TEMPORAL CONTEXT IN RIVER REHABILITATION}

\section{River Diversity}

Do river rehabilitation practices apply openended thinking to river characterization, rather than pigeonholing reality?

To some, the diversity of river forms and processes is an element of natural beauty that is to be cherished, nurtured, and sustained; to others, it presents perplexing complexity that is to be simplified, suppressed, and tamed. Intrinsically, the geoecological viewpoint that underpins rehabilitation promotes the former perspective. Natural rivers vary significantly in different landscape and climatic settings. Variability in discharge regimes and vegetation coverage (driven by climatic setting), slope and confinement (driven by landscape morphology), sediment supply and caliber (driven by geological setting) induces inherent variability in the types of rivers formed. For example, braided rivers are expected in steep, 
sediment-charged, high-relief landscape settings, whereas anastomosing rivers are expected in lowslope, low-sediment-load, low-relief landscape settings.

Countless studies have outlined how geomorphic river diversity reflects a continuum of environmental conditions, along which variants of river morphology and behavior extend from bedrock to fully alluvial types along a gradient of slope and energy conditions (e.g., Church 2002, Montgomery 1999). There is no magic number of variants of river types (Brierley 1996). Any given type of river may be found along a range of environmental conditions. Conversely, differing types of river can exist under a given set of energy and environmental conditions. Although discriminating functions can be used to differentiate the ranges of conditions under which differing types of rivers are found (e.g., Carson 1984, Millar 2000), this is not the same as a threshold-induced circumstance under which a particular type of river occurs within a particular process domain. Other than for managerial convenience, there is little to be gained in using black-box approaches to river classification that pigeonhole reality in ways that are not necessarily appropriate to a given situation or location (Kondolf 2006, Simon et al. 2007). An open-ended approach to river characterization and classification conveys a realistic appreciation of the types and patterns of rivers found in any given place. Respecting this inherent diversity is a key part of an authentic approach to river rehabilitation.

\section{Is the river system naturally heterogeneous or homogeneous?}

Increasing the heterogeneity or complexity of channels and floodplains with the intention of increasing habitat availability and biodiversity is often a key focus in river rehabilitation initiatives. However, blanket applications of the heterogeneity paradigm are not always appropriate. In some instances, the natural geomorphic structure and behavior of a river may be relatively simple. A classic example is a chain-of-ponds river. These discontinuous watercourses comprise swampy valley fill, scour ponds, and indistinct preferential drainage lines (McTaggart et al. 2008). Aquatic flora and fauna have subsequently adapted to this simple structure. The notion of natural simplicity or complexity of geomorphic structure can also be viewed at broader scales. For example, a catchment with two different types of river is no less worthy than a catchment with 10 river types.
In some instances, enhanced heterogeneity of river structure may be an unintended geomorphic response to human disturbance, whereby the diversity of landforms, the range of available habitat, and the range of behavior are enhanced under modified conditions relative to the natural state. For example, incision into basal gravel lag deposits following removal of riparian vegetation and woody debris may induce a more heterogeneous geomorphic structure, with enhanced hyporheic functionality, but the river is now in a much poorer condition (e.g., Hoyle et al. 2008).

Finally, what is natural or expected in terms of system complexity does not merely reflect the range of features and their sensitivity to disturbance. Rather, consideration must also be given to how these units interact and the spatial arrangement or assemblage of these units. Pattern is critical.

\section{Is due regard given to "common" attributes as well as unique values of rivers being managed?}

Effective rehabilitation practice meaningfully relates the unique attributes of any place to more representative attributes, separating the distinctive from the common. Both are vital components of fully functioning riverine environments. Undue regard for unique attributes that comprise $1 \%$ of river course length in a catchment will not engender sustainable outcomes without considering biophysical functionality elsewhere in the system. Care must be taken not to overrepresent uniqueness to the detriment of commonness.

Conversely, many more unique intact, pristine, wilderness, or good-condition rivers form the basis for protection and conservation initiatives. In considering the use of these reaches as reference sites, practitioners have to ask what the reference conditions are representative of (Hilderbrand et al. 2005, Hughes et al. 2005)? Selection of single-site reference conditions runs the risk of inducing uniformity across the landscape toward a preconceived condition. For example, given the significant diversity in character and behavior among, say, meandering or braided rivers, it is inappropriate to set target conditions for all reaches of these river types in relation to pre-existing or even pre-disturbance conditions (e.g., Tockner et al. 2003, Hohensinner et al. 2008). Consideration should also be given to why these remnant reference sites remain intact. Is it simply serendipity (e.g., the terrain was too steep for forest clearance) or is there some inherent resilience to these systems that is not 
representative of other reaches that are no longer intact? The development of a "guiding image" for river rehabilitation should be based on a range of geomorphic insights rather than relying simply on a referential or carbon-copy approach (Hilderbrand et al. 2005) that induces "commonness" across the landscape.

\section{River behavior}

Is due consideration given to the adjusting nature of the river (range of behavior), or do management actions aim to fix rivers in place?

Any rehabilitation strategy that works to a textbook model of river character and behavior, with a fixed sense of what the river should look like and how it is allowed to adjust, is destined to fail (Kondolf 2006, Simon et al. 2007, Wohl et al. 2005). Rather than presenting rehabilitation in terms of static expectations, rehabilitation should be framed in terms of dynamics - the rehabilitation of a living entity to enhance ecological values in relation to natural relationships (Jansson et al. 2005). For this to be achieved, practitioners must recognize the inherent capacity of the system to adjust and change in response to stimuli and disturbance events, and frame rehabilitation strategies accordingly (e.g., Brierley and Fryirs 2005). For example, it is expected that a meandering river will adjust laterally and bank erosion will occur on the concave banks of bends whereas thalweg shift is a key behavioral attribute of a braided river. These adjustments produce the disturbances that create the range of habitat for these different river types.

Just as the range of behavior varies for different types of rivers, so too does the sensitivity of these rivers to adjust (Brunsden and Thornes 1979, Brierley and Fryirs 2005). Some rivers are naturally threshold driven and sensitive to adjustment, whereas others gradually adjust and may be considered resilient to change over longer timeframes. However, the term "resilience" can be used in very different ways by different practitioners (Folke 2006). To ecologists, it conveys a sense of the self-sustaining capacity of a system that is able to adjust and adapt to disturbance events. To engineers, a resilient river is one that responds negligibly to flood events, land-use pressures, climate change, etc. The latter mindset merely extends an ethos of command and control and stability, viewing management success in relation to short-term reductions in maintenance costs, while minimizing unforeseen consequences that may place the project in a poor social light (Palmer et al. 2005). In many instances, this attitude has suppressed the inherent sensitivity of a river in ways that are contrary to the natural behavioral regime of that system. Alternative perspectives, such as space to move, erodible corridor, and channel migration zone programs, expect the river to adjust, such that success is measured by the re-adoption of a wider range of behavioral attributes (Rapp and Abbe 2003, Piégay et al. 2005, Brummer et al. 2006).

\section{Spatial and Temporal Context}

\section{Are system responses to human disturbance differentiated from natural variability of the system?}

Humans have had a fundamental, irreversible, and ongoing impact on the character and behavior of many river systems (e.g., Gregory 2006). However, different types of river have responded in different ways to differing forms of human disturbance. Unravelling the impact of human disturbance from natural variability provides key guidance on the expected character and behavior of a system, determining whether irreversible change has occurred and whether processes have been enhanced or suppressed over time (Brierley et al. 2008). In some instances, human disturbance has increased the range of system behavior. For example, removal of wood and vegetation clearance increases the ease with which a channel is able to adjust (i.e., the river is more sensitive to disturbance). Elsewhere, human disturbance decreases (suppresses) the range of system behavior (e.g., Hughes et al. 2005). For example, flow regulation typically reduces the capacity of a river to adjust its form. If river rehabilitation practice aims to restore process, then the range of behavior required to support a functioning ecosystem needs to be established, even in the light of human disturbance. In some instances, human disturbance may modify the rate and pattern of geomorphic adjustments. For example, incision is a natural process that is induced by exceedence of intrinsic and extrinsic thresholds in cut-and-fill landscapes. Generally, long periods of sedimentation are interrupted sporadically by short phases of incision. Human disturbance modifies this relationship, and "cut" phases tend to become ubiquitous in these settings (Cooke and Reeves 1976, Prosser and Winchester 1996). 
Is the evolutionary pathway of the river being used to inform rehabilitation practice?

Understanding long-term river evolution and its relation to environmental histories should be used to ground studies that scope the future (Brierley and Fryirs 2008). Montgomery (2008) and Wohl (2005) highlight that a solid understanding of what the targeted rivers were like, before undoing or mitigating the degrading influences that currently dominate the system, should be one of the first tasks in river rehabilitation programs. Montgomery (2008: 292) states that "it pays to do the painstaking work of historical sleuthing - even in areas thought to define benchmarks in understanding." Wohl (2005: 14) states that "rivers have a history, and restoration or other management activities conducted in ignorance of this history are a disservice to river ecosystems and to human society." In many instances, antecedent controls exert a significant influence on contemporary river character and behavior (Trofimov and Phillips 1992). Understanding the past allows causes of change (either positive or negative) to be identified, such that rehabilitation practice can address these causes (e.g., Montgomery 2008, Spink et al. 2009). Thus, history matters, and understanding river evolution provides a powerful basis with which to explain why a system is the way it is today and how it may adjust in the future. Management practices that occur in ignorance of this premise are likely to have negative consequences (see Kondolf et al. 2001).

Historical imprints, off-site (lagged) disturbance responses, and complex response (among other factors) ensure that rivers seldom behave as linear cause-effect, equilibrium systems (Phillips 2003). System specific attributes shape the range of potential future pathway(s) of adjustment. It is not possible to identify how close a system lies to a threshold condition, what magnitude or frequency of event will breach this condition, and when that event will occur. Given this inherent uncertainty, a range of scenarios should be presented as potential outcomes to treatment responses (Schmidt et al. 1998, Darby and Sear 2008).

As noted by Wohl et al. (2005), restoration of process is more likely to succeed than restoration aimed at a fixed endpoint. Indeed, thinking in terms of endpoints is questionable, as rivers are dynamic, evolving, nonlinear entities. Do rivers stop adjusting and evolving when they reach an endpoint? Such thinking conveys an inappropriate sense of what rehabilitation is about. Ongoing commitment is required to sustain the process of river repair.

\section{Is each treatment reach appropriately placed in its catchment context?}

Downstream patterns of river types and their process zone dynamics (i.e., whether they act as source, transfer, or accumulation zones; Schumm 1977) are key controls on the operation of flow, sediment, and vegetation interactions. Reach position within a catchment also dictates the degree to which it is affected by disturbance events of various magnitude and frequency (e.g., the upstream progression of a headcut or downstream movement of a sediment slug) (Sear et al. 1995). This is regulated by the degree of (dis)connectivity between reaches, determining if and where disturbance will be manifest in a catchment (Kondolf et al. 2006, Fryirs et al. 2007).

Flow regulation schemes, along with other forms of human disturbance, often result in disconnected river systems. McCully (2001) refers to these systems as silenced rivers. However, the perception that disconnectivity is inherently bad for rivers is a dangerous assumption, as this notion should be viewed in light of the natural degree of connectivity within a system. Indeed, artificially increasing connectivity over natural levels may have negative consequences. Whereas previous work considered rivers as continuously connected conduits (e.g., Vannote et al. 1980), recent work highlights the variability in (dis)connectivity in fluxes of water, sediment, vegetation, macroinvertbrate transport and dispersal (Ward 1989, Moilanen and Nieminen 2002, Kondolf et al. 2006, Fryirs et al. 2007). Not all channels are efficient and effective conduits. In this light, rehabilitation planners must consider whether the systems they are working in are naturally connected or disconnected. Each reach must be viewed in relation to prevailing fluxes at the catchment scale.

Disconnectivity and isolation may have important implications for ecosystem evolution and genetic diversity of particular species. Physically or spatially isolated river basins (or even reaches) may contain unique assemblages of macroinvertebrates, fish, and other organisms that have evolved in a naturally disconnected landscape (Sheldon and Thoms 2006). In geomorphic and hydrological terms, disconnectivity regulates the transport of 
sediment and the filtering of water in landscapes (Fryirs et al. 2007). As a consequence, physically disconnected systems may be more resilient to adjustment as they isolate degrading processes from being manifest in off-site locations.

Analyzing reach position in the catchment relative to threatening processes and limiting factors, and the degree of landscape (dis)connectivity in that catchment, allows practitioners to scope future scenarios for river systems (Brierley et al. 2008). Will a treatment reach experience degrading or positive influences from upstream (e.g., sediment slugs, nickpoints, exotic vegetation or fauna)? From where will the sediment, vegetation, and aquatic fauna be sourced and dispersed to enhance river recovery in the treatment reach? How will rehabilitation of the treatment reach affect other reaches?

To the knowledge of the authors, there are few examples in which these geomorphic principles have been clearly and effectively outlined within catchment management plans, let alone implemented to promote the process of river repair. In this context, questions must be asked about the effectiveness with which scientific principles are guiding river rehabilitation practice (Wohl et al. 2005).

\section{DISCUSSION AND CONCLUSION}

The mindsets of river practitioners are largely contingent on how individuals use knowledge from their own upbringing, experience, and training (Brook 2006, Pahl-Wostl 2006). The themes raised here may challenge dominant and inherent mindsets. Ultimately, however, the questions asked in this paper could be used as a checklist with which to evaluate whether contemporary rehabilitation programs truly reflect the natural values of river systems. Ecosystem-based approaches to river rehabilitation are a relatively recent phenomenon, and inertial effects are bound to prompt resistance. Hopefully, the era of river repair will embrace more integrative, transdisciplinary practices that merge perspectives from natural and engineering sciences and social science (Brierley and Fryirs 2008).

A less optimistic perspective envisages differing sets of agendas and management expediency overwhelming the rehabilitation process. Notions of engineering resilience may threaten biophysical and or sociocultural values of rivers, framed as an alternative static perspective of rivers (i.e., not a hydraulically smooth, trapezoidal channel, but a woody, vegetated, rough, meandering stream that is still locked in place). Oversimplification of river systems through the non-critical application of cookbook practices that fail to consider the inherent naturalness of a given river potentially threaten the very things we are trying to protect. Prospectively, this could railroad the process of river repair. Many rehabilitation strategies continue to apply various myths that promise particular outcomes over unrealistically short timeframes (Hilderbrand et al. 2005, Kondolf 2006, Simon et al. 2007). Unless rehabilitation is viewed as a learning exercise rather than a prescriptive toolkit, efforts are destined to fail. A change in mindsets is required if the era of river repair is to successfully face the environmental challenges of the $21^{\text {st }}$ Century.

Themes outlined in this paper promote naturalness as a platform to frame what we are trying to achieve in river rehabilitation. But we have to ask ourselves, are existing blueprints and vision statements just rhetoric? Are we really doing adaptive management? Are we learning from past mistakes? Are we being too shortsighted? Are we simply rebadging old techniques and ideas in a "softer" context? If so, how can we rectify this? To the authors of this paper, the most effective rehabilitation practices allow the landscape to speak for itself. This requires careful observation, interrogation, interpretation, and monitoring to explain what is happening and why. In a sense, "reading of the landscape" requires that we "think like an ecosystem" (with apologies to Aldo Leopold). Adaptive thinking and learning processes embrace a holistic understanding of river structure, behavior, and evolution (Clark 2002). Each situation is treated separately. Answers are sought from the landscape, not a book or toolbox. This approach moves a practitioner away from preconceived and imported ideas that pigeonhole reality, accommodating what is observed in the real world.

Adaptive thinking and learning is not easy. Indeed, it must be questioned whether it is teachable, or simply requires nurturing of an innate ability. Experiences from tertiary and professional shortcourse teaching by the authors reveal that some practitioners "get it," whereas others simply don't. Understanding of these issues is not a simple or trivial task. Indeed, why would one expect it to be simple? Landscapes and ecosystems are complex 
systems that have unique histories and configurations that will continue to grow and change (Phillips (2007) calls this the perfect landscape). Having said this, overly complicated and convoluted explanations are difficult to communicate, are not necessarily right, and will not necessarily provide appropriate answers. The ability to develop the "just right" approach is particularly challenging.

Ultimately, however, rehabilitation is as much a social process as it is a technical process (Folke 2006, Higgs 2003). The notions discussed here must be viewed in a sociocultural context, reflecting aspirations for particular places. Reconnection with natural processes and variability, appreciation of inherent uncertainty, and direct engagement and involvement (participation) are vital ingredients in the process of river repair (Bradshaw and Borchers 2000, Hillman and Brierley 2008).

The effectiveness of communication strategies is fundamental to meaningful engagement in the rehabilitation process. Benda et al. (2002) and Boulton et al. (2008) highlight impasses that result when scientists, managers, and stakeholders with different mindsets and specialized knowledge structures attempt to work together on transdisciplinary projects (the number of which is slowly increasing across the globe). To address these issues, river rehabilitation should embrace social-learning mechanisms that extend beyond prescriptive toolboxes of techniques and associated tick-box exercises (Pahl-Wostl 2002, 2006). Rather, practitioners must think about and explain what is happening in any given situation. There are significant dangers in the use of generalized knowledge, transferring findings from outside their original context. Geographic training, with its emphasis on the distinctiveness of places, multiple socioeconomic, cultural, and biophysical relationships, spatial links, and cross-scalar thinking, provides an ideal platform with which to ground this process.

In conclusion, the process of river repair requires ongoing commitment and application of proactive rather than reactive measures. Deriving an answer is not the endpoint, implementing a strategy on the ground is not an endpoint, "fixing it" is not an endpoint. Ongoing monitoring and maintenance should be a substantive component of every project (Bernhardt et al. 2005, Wohl et al. 2005). As circumstances change, community engagement and ownership are required to sustain long-term commitment. Reconnecting society to place enhances prospects to improve river health, framing rehabilitation activities as a part of sociocultural developments. Ultimately, the process of river repair is about the actions we take. The future of rivers is in our hands.

Responses to this article can be read online at: http://www.ecologyandsociety.org/voll4/iss 1/art20/ responses/

\section{Acknowledgments:}

Many of the points raised in this paper stem from discussion about river management practice, particularly in Australia, over more than a decade. In particular, we thank Mick Hillman and David Outhet and various practitioners who have attended the River Styles ${ }^{\circledR}$ professional short course for their insights and openness. Funding from the Australian Research Council and Land and Water Australia is gratefully acknowledged.

\section{LITERATURE CITED}

\section{Benda, L. E., N. L. Poff, C. Tague, M. A. Palmer, J. Pizzuto, S. Cooper, E. Stanley, and G. Moglen. 2002. How to avoid train wrecks when using science in environmental problem solving. BioScience 52:1127-1136.}

Bernhardt, E. S., M. A. Palmer, J. D. Allan, G. Alexander, K. Barnas, S. Brooks, J. Carr, S. Clayton, C. Dahm, J. Follstad-Shah, D. Galat, S. Gloss, P. Goodwin, D. Hart, B. Hassett, R. Jenkinson, S. Katz, G. M. Kondolf, P. S. Lake, R. Lave, J. L. Meyer, T. K. O'Donnell, L. Pagano, B. Powell, and E. Sudduth. 2005. Synthesizing U. S. river restoration efforts. Science 308:636-637.

Boulton, A., H. Piégay, and M. Sanders. 2008. Turbulence and train wrecks: using knowledge strategies to the enhance application of integrative river science to effective river management. Pages 28-36 in G. J. Brierley and K. A. Fryirs. editors. River futures: an integrative scientific approach to river repair. Island Press, Washington, D.C., USA. 
Bradshaw, G. A., and J. G. Borchers. 2000. Uncertainty as information: narrowing the sciencepolicy gap. Conservation Ecology 4(1): 7. [online] URL: http://www.consecol.org/vol4/iss 1/art7/.

Brierley, G. J. 1996. Channel morphology and element assemblages: a constructivist approach to facies modelling. Pages 263-298 in P. Carling and M. Dawson, editors. Advances in fluvial dynamics and stratigraphy. Wiley Interscience, Chichester, UK.

Brierley, G. J., and K. A. Fryirs. 2005. Geomorphology and river management: applications of the River Styles framework. Blackwell, Oxford, UK.

Brierley, G. J., and K. A. Fryirs, editors. 2008. River futures: an integrative scientific approach to river repair. Island Press, Washington, D.C., USA.

Brierley, G. J., K. A. Fryirs, A. Boulton, and C. Cullum. 2008. Working with change: the importance of evolutionary perspectives in framing the trajectory of river adjustment. Pages 65-84 in G. J. Brierley and K. A. Fryirs, editors. River futures: an integrative scientific approach to river repair. Island Press, Washington, D.C., USA.

Brook, I. 2006. Restoring landscapes: the authenticity problem. Earth Surface Processes and Landforms 31:1600-1605.

Brummer, C. J., T. B. Abbe, J. R. Sampson, and D. R. Montgomery. 2006. Influence of vertical channel change associated with wood accumulations on delineating channel migration zones, Washington, USA. Geomorphology 80:295-309.

Brunsden, D., and J. B. Thornes. 1979. Landscape sensitivity and change. Transactions of the Institute of British Geographers NS4:463-484.

Carson, M.A. 1984. The meandering-braided river threshold: a reappraisal. Journal of Hydrology 73:315-334.

Church, M. 2002. Geomorphic thresholds in riverine landscapes. Freshwater Biology 47:541557.

Clark, M. J. 2002. Dealing with uncertainty: adaptive approaches to sustainable river management. Aquatic Conservation: Marine and Freshwater Ecosystems 12:347-363.
Cooke, R. U., and R. W. Reeves. 1976. Arroyos and environmental change in the American Southwest. Clarendon Press, Oxford, UK.

Darby, S., and D. Sear, editors. 2008. River restoration: managing the uncertainty in restoring physical habitat. Wiley, Chichester, UK.

Everard, M., and A. Powell. 2002. Rivers as living systems. Aquatic Conservation: Marine and Freshwater Ecosystems 12:329-337.

Folke, C. 2006. Resilience: the emergence of a perspective for social-ecological systems analyses. Global Environmental Change 16:253-267.

Fryirs, K., G. J. Brierley, N. J. Preston, and M. Kasai. 2007. Buffers, barriers and blankets: the (dis) connectivity of catchment-scale sediment cascades. Catena 70:49-67.

Gregory, K. J. 2006. The human role in changing river channels. Geomorphology 79:172-191.

Higgs, E. 2003. Nature by design: people, natural process and ecological restoration. MIT Press, Cambridge, Massachusetts, USA.

Hilderbrand, R. H., A. C. Watts, and A. M. Randle. 2005. The myths of restoration ecology. Ecology and Society 10(1): 19. [online] URL: http: //www.ecologyandsociety.org/vol10/iss1/art19/.

Hillman, M., and G. J. Brierley. 2005. A critical review of catchment-scale stream rehabilitation programmes. Progress in Physical Geography 29:50-70.

Hillman, M., and G. J. Brierley. 2008. Restoring uncertainty: translating science into management practice. Pages 257-272 in G. J. Brierley and K. A. Fryirs. editors. River futures: an integrative scientific approach to river repair. Island Press, Washington, D.C., USA.

Hohensinner, S., M. Herrnegger, A. P. Blaschke, C. Habereder, G. Haidvogl, T. Hein, M. Jungwirth, M. Weiâ. 2008. Type-specific reference conditions of fluvial landscapes: a search in the past by 3D-reconstruction. Catena 75(2):200 215. doi:10.1016/j.catena.2008.06.004.

Hoyle, J., A. Brooks, G. J. Brierley, K. Fryirs, and J. Lander. 2008. Spatial variability in the 
timing, nature and extent of channel response to typical human disturbance along the upper Hunter River, New South Wales, Australia. Earth Surface Processes and Landforms 33:868-889

Hughes, F. M. R., A. Colston, and J. O. Mountford. 2005. Restoring riparian ecosystems: the challenge of accommodating variability and designing restoration trajectories. Ecology and Society 10(1): 12. [online] URL: http://www.ecolog yandsociety.org/vol10/iss1/art12.

Jansson, R., H. Backx, A, J, Boulton, M. Dixon, D. Dudgeon, F. M. R. Hughes, K. Nakamura, E. H. Stanley, and K. Tockner. 2005. Stating mechanisms and refining criteria for ecologically successful river restoration: a comment on Palmer et al. (2005). Journal of Applied Ecology 42:218222.

Junker, B., and M. Buchecker. 2008. Aesthetic preferences versus ecological objectives in river restorations. Landscape and Urban Planning 85:141-154.

Kondolf, G. M. 2006. River restoration and meanders. Ecology and Society 11(2): 42. [online] URL: http://www.ecologyandsociety.org/vol11/iss2/ art42/.

Kondolf, G. M., A. J. Boulton, S. O'Daniel, G. C. Poole, F.J. Rahel, E.H.Stanley, E. Wohl, A. Bång, J. Carlstrom, C. Cristoni, H. Huber, S. Koljonen, P. Louhi, and K. Nakamura. 2006. Process-based ecological river restoration: visualizing three dimensional connectivity and dynamic vectors to recover lost linkages. Ecology and Society 11(2): 5. [online] URL: http://www.ecologyandsociety.org/vol11/ iss2/art5/.

Kondolf, G. M., M. W. Smeltzer, and S. Railsback. 2001. Design and performance of a channel reconstruction project in a coastal California gravel-bed stream. Environmental Management 28: 761-776.

McCully, P. 2001. Silenced rivers: the ecology and politics of large dams. Zed Books, Atlantic Highlands, New Jersey, USA.

McTaggart, B., J. Bauer, D. Goldney and A. Rawson. 2008. Problems in naming and defining the swampy meadow-an Australian perspective. Journal of Environmental Management 87:461473.

Millar, R. G. 2000. Influence of bank vegetation on alluvial channel patterns. Water Resources Research 36(4):1109-1118.

Moilanen, A., and M. Nieminen. 2002. Simple connectivity measures in spatial ecology. Ecology 83:1131-1145.

Montgomery, D. 2008. Dreams of natural streams. Science 319:291-292.

Montgomery, D. R. 1999. Process domains and the river continuum. Journal of the American Water Resources Association 35(2):397-410.

Pahl-Wostl, C. 2002. Towards sustainability in the water sector: the importance of human actors and processes of social learning. Aquatic Sciences 64:394-411.

Pahl-Wostl, C. 2006. The importance of social learning in restoring the multifunctionality of rivers and floodplains. Ecology and Society 11(1): 10. [online] URL: http://www.ecologyandsociety.org/vol11/ iss1/art10/.

Palmer, M. A., E. Bernhardt, and J. D. Allan. 2005. Standards for ecologically successful river restoration. Journal of Applied Ecology 42:208217.

Phillips, J. D. 2003. Sources of nonlinearity and complexity in geomorphic systems. Progress in Physical Geography 27:1-23.

Phillips, J. D. 2007. The perfect landscape. Geomorphology 84:159-169.

Piégay, H., S. E. Darby, E. Mosselman, and N. Surian. 2005. A review of techniques available for delimiting the erodible river corridor: a sustainable approach to managing bank erosion. River Research and Applications 21(7):773-789.

Prosser, I. P., and S. J. Winchester. 1996. History and processes of gully initiation and development in eastern Australia. Zeitschrift fur Geomorphologie, Supplement Band 105:91-109. 
Rapp, C. F., and T. B. Abbe. 2003. A framework for delineating channel migration zones. Washington State Department of Ecology, Publication No. 03-06.027. Olympia, Washington, USA.

Schmidt, J. C., R. H. Webb, R. A. Valdez, G. R. Marzolf, and L. E. Stevens. 1998. Science and values in river restoration in the Grand Canyon. BioScience 489:735-747.

Schumm, S. A. 1977. The fluvial system. Wiley, New York, New York, USA.

Sear, D. A., M. D. Newson, and A. Brookes. 1995. Sediment-related river maintenance: the role of fluvial geomorphology. Earth Surface Processes and Landforms 20:629-647.

Sheldon, F., and M. C. Thoms. 2006. Relationships between flow variability and macroinvertebrate assemblage composition: data from four Australian dryland rivers. Regulated Rivers: Research and Management 22(2):219-238.

Simon, A., M. Doyle, M. Kondolf, F. D. Shields, Jr., B. Rhoads, and M. McPhillips. 2007. Critical evaluation of how the Rosgen classification and associated "natural channel design" methods fail to integrate and quantify fluvial processes and channel response. Journal of the American Water Resources Association (JAWRA) 43(5):1117-1131. doi:10.1111/ j.1752-1688.2007.00091.X

Spink, A., K. Fryirs, and G. J. Brierley. 2009. The relationship between geomorphic river adjustment and management actions over the last 50 years in the upper Hunter catchment, NSW, Australia. River Research and Applications, in press.

Tockner, K., J. V. Ward, D. B. Arscott, P. J. Edwards, J. Kollmann, A. M. Gurnell, G. E. Petts, and B. Maiolini. 2003. The Tagliamento river: a model ecosystem of European importance. Aquatic Science 65:239-253.

Trofimov, A. M., and J. D. Phillips. 1992. Theoretical and methodological premises of geomorphological forecasting. Geomorphology 5:203-211.

Vannote R. L., G. W. Minshall, K. W. Cummins, J. R. Sedell, and C. E. Cushing. 1980. The river continuum concept. Canadian Journal of Fisheries and Aquatic Sciences 37:130-137.

Ward, J. V. 1989. The four-dimensional nature of the lotic ecosystem. Journal of the North American Benthological Society 8:2-8.

Wohl, E. 2005. Virtual rivers: understanding historical human impacts on rivers in the context of restoration. Ecology and Society 10(2): 2. [online] URL: http://www.ecologyandsociety.org/vol10/iss2/ $\underline{\operatorname{art} 2 / .}$.

Wohl, E., P. L. Angermeier, B. Bledsoe, G. M. Kondolf, L. MacDonnell, D. M. Merritt, M. A. Palmer, N. L. Poff, and D. Tarboton. 2005. River restoration. Water Resources Research 41: W10301. doi:10.1029/2005WR003985.

Wohl, E., and D. J. Merritts. 2007. What is a natural river? Geography Compass 1(4):871-900. 